BIAEOSTOCKIE

TEKI

HISTORYCZNE

TOM 7/2009

ISSN 1425-1930

\title{
Barbara Skarga 25 X 1919 - 18 IX 2009
}

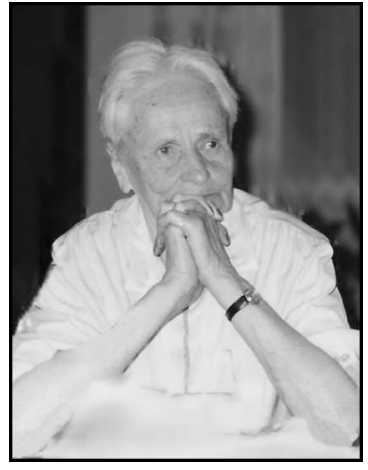

18 września 2009 roku zmarła Profesor Barbara Skarga - jedna z najwybitniejszych i najpiękniejszych postaci polskiego życia intelektualnego i publicznego. Słowo „zmarła”, zamiast eufemistycznego „odeszła”, jest tu istotne, bo jedynie godne Jej doświadczenia życiowego. W swoim życiu widziała wiele śmierci, w tym tych najgorszych, inspirowanych zideologizowaną polityką. Widziała, że wykonawstwo tej polityki zawsze spoczywało na barkach ludzi zwyczajnych. Pisała więc, „człowiek to nie jest piękne zwierzę”. Nie popadła jednak z tego powodu w nienawiść, ani zgorzknienie, nie znosiła też, kiedy inni w imieniu osób takich jak Ona, doświadczonych przez historię, praktykowali nienawiść w polityce. Uważała, że nienawiść, zwłaszcza uwznioślona, skierowana przeciw narodom i państwom, a nie konkretnym ludziom, to rzecz, historycznie rzecz biorąc, szczególnie niebezpieczna niezależnie od tego, kto i w jakim celu ją praktykuje.

Mimo wszystkich doświadczeń w przeszłości i rozczarowań w teraźniejszości nie opuszczała Jej nadzieja na znajdowanie ludzi przyzwoitych, zbuntowanych przeciwko przeciętnie wyznawanym w społeczeństwie wartościom. Do ostatnich lat swego życia znajdowała takich i otwierała się na nich. To dlatego, inaczej niż to jest na ogół, krąg towarzyski Pani Profesor nigdy nie był ostatecznie zamknięty. Wartościowym ludziom Pani Profesor poświęcała życzliwe i taktowne zainteresowanie, była niezwykle ciepła w kontaktach i każda taka osoba czuła się szczególna, wybrana. Mówiąc inaczej, językiem Jej „Tercetu metafizycznego”, mimo iż znikały po kolei ważne dla Niej światy, nie ustawała w trudzie budowania na ich miejsce światów nowych. Jest to wysiłek tym bardziej godny szacunku, gdyż Pani Profesor była w pełni świadoma, że nie jesteśmy w stanie zapanować nad przestrzenią naszego świata. Wprawdzie z obszernej przestrzeni świata fizycznego „wycinamy niewielką jej część” i nazywamy ją własną, pragniemy wyprać ją „,z wszelkich nie należących do niej elementów”, ale nigdy 
do końca nie jest to możliwe, „one wracają, one są silniejsze, one ją przepełniają”, choć nie należą do nas, „są nieznośne”. Mimo tej gorzkiej wiedzy Pani Profesor dbała o swoje światy w szczególny sposób, broniąc ich przed przenikaniem do nich osób obcych Jej duchowo, nieautentycznych. Usiłowała niemożliwe uczynić możliwym i udawało się Jej to. Taka postawa wymagała odwagi bycia sobą, bycia wierną sobie, a tym samym nierozumianą przez niektórych. To bodaj jeden z najtrudniejszych rodzajów odwagi, a jej znaczenie, niesłusznie, jest niedoceniane przez większość.

Pani Profesor była niezwykła z powodu fundamentalnego, bardzo zobowiązującego przekonania przyświecającego całemu Jej życiu. Jest to przeświadczenie o tym, że nasze światy nie są wyłącznie naszą prywatną sprawą, ale wydarzeniami o metafizycznym sensie i historycznym znaczeniu. Są one jedynymi miejscami, w których i poprzez które metafizyka objawia się praktycznie, nie deklaratywnie, i poprzez które dzieje się historia. Osoby podkreślające ich prywatność i niezaangażowanie w sprawy wielkiego, politycznego świata, działają w złej wierze, uciekają od odpowiedzialności, przed którą, metafizycznie rzecz ujmując, uciec się nie da. Zło bowiem przychodzi w świat nie inaczej niż poprzez każdego z ludzi. Dlatego przekonanie Mikołaja Bierdiajewa, że „wolny duchem jest ten, kto przestał odczuwać historię jako narzuconą z zewnątrz, a zaczął ją odczuwać jako wewnętrzne wydarzenie rzeczywistości duchowej"2, najdokładniej i najpełniej oddaje stosunek Pani Profesor do rzeczywistości społecznej i naszego w niej miejsca.

To nie same racje rozumowe, ale doświadczenie życiowe Pani Profesor nakazywało Jej pozostać wierną metafizyce jako źródłu uniwersalnych wartości i sensu. Ta wierność też wymagała odwagi, albowiem jej obiekt - metafizyka był filozoficznie niemodny. Niestety, filozofia, ta najważniejsza z nauk, nie jest wolna od mód, jakby nie dorastając tym samym do swego miana. Pani Profesor godziła się jednak z tym, że filozofia, jak i historia, „robiona” jest przez konkretnych, a nie abstrakcyjnych, ludzi ze wszystkimi tego konsekwencjami. Jedną z tych konsekwencji jest to, że nawet najwybitniejszego filozofa metafizyki nie można nauczyć, ani mu jej narzucić, że potrzeba metafizyki musi wypływać nie tylko z rozumu, ale z najgłębszych emocjonalnych potrzeb warunkowanych osobistym doświadczeniem. Dopóki ich nie poczujemy, metafizyka nie będzie mieć do nas dostępu.

Prowadzone przez Panią Profesor seminarium nie zapoznawało tego ludzkiego wymiaru filozofii. Dlatego było, z jednej strony, miejscem poszukiwania filozoficznej prawdy, gdzie metafizyka Pani Profesor jawiła się zaledwie jako jedna z możliwych propozycji, z drugiej zaś unikalnym spotkaniem osobowości pod

1 B. Skarga, Tercet metafizyczny, Kraków 2009, s. 34.

2 N. Bierdiajew, Smyst istorii, Moskwa 1990, s. 30. 
każdym względem niepodobnych. Dla niektórych z nich szacunek i podziw dla Pani Profesor był jedyną łączącą ich ze sobą nicią. Dlatego Jej śmierć, to także śmierć seminarium nie tylko jako pewnego projektu poznawczego, ale przede wszystkim pewnego prywatnego świata, który zdolna była stworzyć wyłącznie Ona i który w takiej właśnie konfiguracji ludzkiej był ważny wyłącznie dla Niej.

Równie osobisty charakter nadawała Pani Profesor Barbara Skarga swej współpracy z instytucjami, wydawnictwami i czasopismami. Czuliśmy się wyróżnieni, bo właśnie ten bardzo osobisty, przyjacielski i życzliwy stosunek do konkretnych osób przywiódł Ją na Uniwersytet w Białymstoku i Wydział Historyczno-Socjologiczny. Swoimi wykładami inaugurowała na naszej Uczelni ważne wydarzenia - rok akademicki 2005/2006 oraz Festiwal Nauki i Sztuki w roku 2007. Wygłoszone podczas tych uroczystości teksty $O$ obywatelstwie i $O$ uniwersytecie wydrukowały Białostockie Teki Historyczne. Pozostaną one na zawsze dla nas, wykładowców i studentów naszej Uczelni, źródłem inspiracji intelektualnej i moralnej oraz drogą po Niej pamiątką i cennym wspomnieniem.

Oczywiście, śmierć Pani Profesor Barbary Skargi jest stratą nie tylko dla osób bezpośrednio Ją znających. Być może poczucie straty dla tych, co Jej nigdy osobiście nie poznali, jest jeszcze bardziej dotkliwe niż dla nas. $Z$ pewnością była osią światów wszystkich przyzwoitych ludzi, funkcjonujących najczęściej w rozproszeniu i osamotnieniu. Mówiła do nich swoją twórczością, postawą życiową i była przez nich słyszana. Utożsamiali się z systemem wartości Pani Profesor i czerpali siłę z tego, że poprzez Nią jest on widoczny, stanowi żywą kontrpropozycję dla wszechobecnego karierowiczostwa, nihilizmu, cynizmu, konsumpcjonizmu, niezakorzenionego w żadnym systemie wartości powierzchownego indywidualizmu. Tę społecznie ważną rolę Pani Profesor pełniła w sposób naturalny, samym swoim Istnieniem i sposobem bycia. Teraz bardzo trudno będzie komuś innemu zastąpić Ją w Niej, udźwignąć podobny ciężar.

Może do pełnienia takiej roli po prostu trzeba się urodzić...

Ewa Matuszczyk

Białystok 